\title{
Karl Polanyi, the New Deal, and the Green New Deal
}

\begin{abstract}
In this paper I present an analysis of those aspects of Karl Polanyi's social and political thought that relate to environmentalism today. I discuss whether or not he prefigured the degrowth movement, before focusing on his understanding of the New Deal. At time of writing, the prospect appears likely of a return, at the global scale, of economic slump, mass unemployment, and ecological crisis, the background conditions to which, on the national scale, Roosevelt's New Deal was responding. The paper concludes by drawing lessons for possible Green New Deals.
\end{abstract}

KEYWORDS: Karl Polanyi, New Deal, Green New Deal, degrowth, embeddedness

\section{Introduction}

The present conjuncture is characterised by a multi-dimensional crisis featuring mass unemployment and social polarisation, significant and possibly protracted economic slump and escalating environmental crises as well as resurgent epidemiological terrors. ${ }^{1}$ The picture is not closely comparable to the 1930s, yet the similarities and resonances are apparent—including, not least, in the field of environmental politics. The best-known type of policy programme that aims to simultaneously combat economic and climate crises, the Green New Deal (GND), takes its name from Depression-era America.

In this essay I approach the New Deal through the work of Karl Polanyi, and assess lessons for GND programmes. The essay begins by situating Polanyi against the sweep of twentiethcentury 'progress' and crises. Secondly, I inquire into Polanyi's environmentalism, noting some likenesses between his views and those that circulate within the degrowth movement

\footnotetext{
${ }^{1}$ Pilot versions of this paper were presented at the 'Great Transformation At 75' conference, Bennington College, Vermont, October 2019, and as the preface to the 2020 Japanese translation of Dale (2016c).
} 
today. Thirdly, I provide an exposition and critique of Polanyi's approach to the New Deal. This, finally, provides materials through which to re-examine the GND today.

\section{Corrosions of Progress, then and now}

Karl Polanyi was a child of the nineteenth century but his political thought was baked in the furnaces of 1914-45. He belonged to a generation many of whom who had grown up swaddled in a Whiggish faith in the inevitability of social progress (Dale 2009). Liberals and many socialists too, including Polanyi, accepted the comforting promise that the onward march of capitalism would necessarily expand liberties and democracy, that the advance of science would overcome many of the challenges facing humanity, and that peace would flourish, by virtue of intensifying commercial exchange and international cooperation. Cures would be devised for cholera and other pathogens, and famine would be defeated. Working together, liberal politics, rational science and market economics would bridle and tame the four horsemen.

In 1914, however, the dream shattered. Four years later, Spanish Flu scythed through the warweakened world. As far as I know, it bypassed Polanyi, although in 1917-18 he was hospitalised by another mass killer of the age, typhus. In the 1930s, famine returned to Europe, notably the Ukraine, while livelihoods worldwide were ravaged during the Great Depression. In the USA this included ecological crisis in the Great Plains, where drought combined with the soil erosion occasioned by settler colonialism and cash-crop agriculture to drive dust-bowl desertification (Holleman 2017). All of these, followed by war and the death camps, exposed, for all to see, some terrifying propensities of the capitalist system. (In that system I include 1930s Ukraine, for reasons summarised in Dale (2017).)

When Polanyi wrote The Great Transformation, during World War II, the Progress narrative was ailing, but colour soon returned to its cheeks. The 'good guys' won the war, eradicated 
Nazism, and soldered the world economy back together. Progress powered on, full-throttle, as manifested in miraculous advances in prosperity, literacy, and life expectancy. In North America, where Polanyi lived, but also in his native Hungary and beyond, welfare institutions were constructed. Medical advances were breath-taking too. Typhus and several other diseases were largely vanquished, with some, notably smallpox, being eradicated. Socialists of socialdemocratic and orthodox-communist stripes found common ground with liberals in the belief that Progress was enjoying another splendid stride. (Whether Polanyi belonged to this camp is the subject of some debate.) A decade or two after Polanyi's death, as the neoliberal era dawned, eventually stretching from around 1980 to the present, Progress appeared to mainstream opinion to be achieving giddy heights, exemplified in the marvels of computing and information technology, economic globalisation, the worldwide expansion of democratic government and its triumph over communism. Yet the same decades saw a widespread erosion of labour union strength and welfare rights, and if democracy was globalising it was decidedly off-colour. The left, including all who took their cue from Polanyi, understood neoliberalism as social regression, a perception that gained further plausibility during the Great Recession of 2007-9 and the ensuing age of austerity.

The conjuncture that is opening now, as I write these lines in May 2020, will be overshadowed not only by the recent tendency of global capitalism to sharper economic crises but also by its generation of biological and environmental threats on an escalating scale. That humans create conditions favourable to the thriving of epidemic diseases has long been apparent. In the earliest agrarian civilisations, the concentrations of people alongside livestock facilitated the transmission of pathogens and parasites, the generation of new zoonotic diseases - those that jump from nonhuman animals to humans (Scott 2017). These processes sharply accelerate under capitalist conditions. As Rob Wallace spells out in Big Farms Make Big Flu (2016), agribusiness 'has entered a strategic alliance with influenza.' Factory livestock farming 
establishes the optimal environment for pathogens to spread. Once a virus is in a chicken, duck or pig, the next hosts are easy meat: lined up cheek by jowl, with near-identical genes. The large majority of new or emerging diseases that infect humans have originated in wild or domesticated animals, and the last four decades have seen a two- to three-fold increase in zoonotic spillover events (Berger 2020). In the case of Covid-19, the linkages from bat to pangolin (a likely intermediate host) to human appear accidental, but if we look behind the xenophobic headlines we see how system-conditioned they are. The aetiology of the crisis, in other words, was mapped by humanity's relationship to wilderness and its fauna under capitalist conditions. Almost all the world's wildernesses have been encroached and the primary forests have been decimated. Deforestation and other forms of habitat encroachment compress the remaining reserves of wildlife, bringing them up close to humans. Meanwhile the demand for luxury wild animal products continues. China accommodates a lucrative trade in wild animals for food and medicine; and, as the recent popular series Tiger King shows, exotic breeding programs and traffic in wild animals is not a preserve of East Asian or African nations but is thriving in the West too. In all these ways the coronavirus crisis is not simply 'natural.' Rather, it arises within a natural realm that has been ripped and striated by capitalist forces. ${ }^{2}$

The perils of Covid-19 are trivial in comparison with those of climate breakdown and biodiversity loss. Yet the epidemiological and environmental crises share some root causes, above all capitalism's predatory relationship with the natural environment. Climate change is predicted to drive 'substantial global increases in the passing of novel diseases from mammals to humans by 2070,' and will also greatly increase the range of insect-borne diseases (Dunne 2020). Both Covid-19 and climate change illustrate a troubling tendency to the downplaying of dangers where their amelioration would rub against corporate interests. The risks of climate

\footnotetext{
${ }^{2}$ This and the next paragraph draw on Bhattacharya and Dale (2020).
} 
breakdown are well known, they are existential, yet next to nothing is being done to mitigate them-as is shown graphically each month in the carbon dioxide measurements from the Mauna Loa observatory. Even in this year of coronavirus-triggered global slump, the expected emissions cuts are at best equal but more likely less than the rates of decrease required every year over the next decades to avoid disastrous climate impacts for much of the world (Le Quéré et al. 2020; Milman 2020). Similar applies to the threat of disease. Public health experts and social scientists have for years been warning of a repeat of a viral outbreak similar in scope and lethality to the 1918 pandemic (e.g. Chase-Dunn and Lawrence 2011). As with climate breakdown, many corporations and governments resisted these warnings, and Covid-19 caught them unprepared (Boffey 2020; Doward 2020).

\section{Our ancestors' weird undertakings}

Polanyi is well known as a critic of the market system, but how should we characterise his approach to the natural environment? What filiations exist between his programmatic ideas and those of environmentalists today? Do his theories lend support to eco-modernisation positions, including on carbon markets, as Wim Carton (2014) contends, or to a degrowth approach, as argued by Diana Stuart and her colleagues (2019)? One can find biographical and textual support for both positions. On one hand, Polanyi was a child of the Enlightenment. He was heavily invested not simply in the bourgeois conception of Progress but also, in his younger years, in the belief that economic growth, political democracy and the market economy march hand in hand. Later in life, in the 1930s, his socialist vision acquired a heavy-industrial slant. He marvelled at the forced industrialisation of Soviet Russia. Rapid economic growth, he supposed, was a sign of that system's superiority over its rivals. 
On the other hand, one can read Polanyi as an environmentalist in sensibility, and even as a degrowther avant la lettre. ${ }^{3}$ Such a narrative would begin with his passion for Russian narodism when a youth. ${ }^{4}$ It would note his fascination with scientific and technological advance but would emphasise his Romantic misgivings over the scientific revolution, which appeared to be troublingly outpacing humankind's moral progress. In one article (Polanyi early 1920s b) he describes the oil industry as the 'fantasy monster of modern capitalism' which, like an 'iron worm is impossible to injure; it is a tank that crushes everything in its path.' In another (Polanyi 1922), he criticises schools of thought for which 'machine production' had become 'a dogma,' one 'that regards the unlimited expansion of material welfare as a natural law.' In a third (Polanyi early 1920s a), he refers to 'the shadow' of economic development, which 'silences rather than reassures us.' The same article goes on,

'Today we openly admit that we are afraid. Tremendous uncertainty pervades our lives. [...] The development of technology only adds fuel to our fear. Ten years ago we were happy if the news services were improved, traffic accelerated, or advances in chemistry were achieved; we were proud of the wireless telegraph, with which we were conquering space. We had faith in science, because it improved our welfare. Today the reverse holds true: when we discover new, modern explosives [...] general staffs begin to compete with each other, with bombs filled with toxic gases. [...] We no longer rejoice in technological progress but fear it. Instead of medicines, chemistry is producing poisons; instead of life buoys, technology is designing electric chairs.'

\footnotetext{
${ }^{3}$ Polanyi also developed a critique of the concept of scarcity that degrowthers share. For him, scarcity is an empirical and socially constructed phenomenon; its presence depends upon natural and social factors and cannot be assumed a priori. It cannot be assessed independently of its meanings in a given cultural context. For development of this point, see Dale (2012).

${ }^{4}$ Narodism was an agrarian socialist movement in nineteenth-century Russia.
} 
This broadly Rousseauian outlook took shape during Polanyi's time in Budapest and Vienna but it gained its full form when he moved to London in the early 1930s. There, he threw himself into a debate on the social consequences of the industrial revolution in Britain. In one corner were those who deplored the harmful effects of industrialisation on the poor, and the violence of the socio-cultural rupture. In the other, the emphasis was on the all-round benefits of economic growth and the incremental character of socio-economic change. Polanyi sided forcefully with the first, and it was in developing his own distinctive approach to the debate that he came up with the theory of 'fictitious commodities.' This concept can be read as the core of his environmental political economy. It focuses on land, labour and capital (or 'money'), the trinity of the revenue sources identified in classical political economy. Labour, land and money, he writes (2001: 75), 'are essential elements of industry,' and in capitalist society the markets for all three 'form an absolutely vital part of the economic system.' Yet they are 'fictitious commodities,' in that they have not been produced for sale. 'What we call land,' he maintains (2001: 187), 'is an element of nature inextricably interwoven with man's institutions. To isolate it and form a market for it was perhaps the weirdest of all the undertakings of our ancestors.'

The commodification of land did not, in Polanyi's analysis, prove immediately toxic to the natural environment. As an example he cites the USA prior to 1890 , a society characterised by 'a free supply of land, unskilled labour and paper money' (Polanyi 1945). This combination did not produce 'the lethal dangers to the fabric of society, to man and soil, which are otherwise inseparable from 'self-adjusting' capitalism.' Yet the nineteenth-century USA was an exception that proved the rule. The generalised logic of commodification was indeed ruinous. The 'transformation of the natural and human substance of society into commodities' leads to a profound 'dislocation' of social relationships which ultimately threatens our 'natural habitat with annihilation' (Polanyi 2001: 44). By subjecting land 'to the supply-and-demand 
mechanism of the market,' human society risks undermining 'the integrity of the soil and its resources, ... the abundance of food supplies, [and] even the climate of the country which might suffer from the denudation of forests, from erosions and dust bowls' (Polanyi 2001: 193). Polanyi wrote nothing on the natural environment as such, and little even on nature-society relations, but this, his core thesis, carries a clear political-ecological thrust. A free market economy, he proposes in The Great Transformation (2001: 3), could not exist 'for any length of time without annihilating the human and natural substance of society.' Polanyi's contention is that constructing a global economy on the basis of commodified land, labour and money was a recipe for a disastrous 'disembedding' of economy from society, whereby the market came to dominate social life as a whole, bringing forth a sorcerer's-apprentice world of untrammelled market forces which, although human creations, lie beyond conscious human control. This lay behind the geopolitical strife, economic crises, and socio-political catastrophes of the first half of the twentieth century.

The distinction between society and the market economy is normally thought of as the organising dichotomy around which The Great Transformation is constructed. Yet it maps to, and in the narrative is preceded and predated by, another contrast: of habitation and improvement (Holmes 2018: 29). Polanyi found these terms in an English privy council memorandum of 1607, drawn up in response to widespread agitation—including rioting — over enclosures. The document recommends that some forms of enclosure should be permitted, so long as 'the poor man shall be satisfied in his end: Habitation; and the gentleman not hindered in his desire: Improvement' (Polanyi 2001: 36). In his construction of the habitationimprovement couplet, Polanyi is threading together three issues: social class, economic order, and the pace of change. He skates over social class rather briefly, but does make clear that wherever improvement carries the day, the gentlemen bend the economic order to their greed while 'the poor man clings to his hovel.' And what economic order is best suited to the desires 
of the gentlemen? Above all, an unregulated market system. Such a system tends to facilitate efficiency gains and economic growth, Polanyi suggests, but at the cost of 'habitation,' in its social and environmental senses. As a consequence of the "vast movement of economic improvement' in nineteenth-century England, accompanied by the inevitable 'social catastrophe' (Polanyi, 2001: 40), non-market institutions arose to defend the interests of habitation. It was this dynamic contradiction that he theorised as the 'double movement,' and at times he appears to see improvement as the accelerator pedal and habitation as the brake. Where socioeconomic change is 'undirected,' Polanyi suggests (2001: 35), it tends to be too rapid, for upon the rate of change depends 'whether the dispossessed could adjust themselves to changed conditions without fatally damaging their substance, human and economic, physical and moral.' A process of undirected change, 'the pace of which is deemed too fast,' he enjoins (2001: 35), 'should be slowed down, if possible, so as to safeguard the welfare of the community.'

In formulating political demands in the language of tempo, Polanyi's words have a conservative ring, and yet the portents of the new and more progressive society that he hoped to see were beginning to emerge during the Great Depression in Stalin's Five-Year Plans and Roosevelt's New Deal, both of which required rapid institutional change. In our crisis-ridden world today, it is clear that 'habitation,' in terms of human welfare and a habitable environment, requires a radical deceleration of capital accumulation and this, in turn, demands an equally radical pace of institutional change. With this in mind, let us turn to look in some detail at Polanyi's evaluation of the New Deal, and thence to implications for the initiatives that are today gathering under the banner of the GND.

\section{Polanyi and the New Deal}


Only Hannes Lacher and myself have studied Polanyi's evolving views on the New Deal in any detail and with attention to his unpublished writings. We both identify ambivalences and ambiguities. Polanyi, in Lacher's rendition (2006: 142), did not expect 'the New Deal to represent the final form of an economy embedded in society,' yet he 'certainly took it to be a first step in a gradual reassertion of the primacy of cultural and political institutions over the market.' In partial contradiction of this view, he goes on, Polanyi also came to see the New Deal as "just a variant of "liberal capitalism" - it did not "constitute a re-embedding of the economy' (Lacher 1999). Polanyi, indeed, never 'considered ... that the New Deal was embarked on a journey towards socialism' (Lacher 2020). Lacher makes much of purported discrepancies between our accounts. Yet to me these appear exaggerated. They rely on misrepresentations. ${ }^{5}$ At least on the key points of interpretation, agreement reigns.

My own account has appeared in separate strands (Dale 2016b, 2016c). I begin by noting that, initially, Polanyi (1933) was critical of Roosevelt, even accusing his 'Brain Trust' of advocating 'plan-economic fascism.' Yet before long he came to see Roosevelt's abandonment of the gold standard as a milestone in the global shift away from the straightjacket of liberal economics. By the Second New Deal (1935-6) he had turned enthusiast, and the Tennessee Valley Authority, organising public investment in rural electrification, made a terrific impression. He remarked (Polanyi 1936) on the 'important change' occurring in the position of the American working class, and prophesied that out of the depths of the Great Depression, 'a great transformation in the USA is growing.' This was, to my knowledge, his first use of 'great transformation.' It refers not only to the impending social changes in the USA, but to a worldwide transition, whereby all nations in the interwar period were developing into

\footnotetext{
${ }^{5}$ For example, in Lacher's reading (2020), "Dale suggests that the policies Roosevelt adopted after 1935 came close to realizing Polanyi's vision of a re-embedding of the market." This is a misrepresentation.
} 
'complete and coherent units, with closely interdependent parts' (Polanyi, in Dale 2016a). As Polanyi (1940) explained, in a letter to his wife from the USA,

'The present world crisis is ultimately due to market-economy, as the first phase of industrial civilization. The past quarter century was a result of the dissolution of the international economic system based on that economy. [...] The reform of the economic system had to be achieved on pain of destruction of society; the alternative was between a democratic or an anti-democratic method of achieving it. In Europe the democratic method proved unavailing; thus fascism became inevitable. America may be an exception, owing to the first years of the New Deal. Still - this is a world process; the reintegration of international life must still be achieved.'

This letter anticipated the central argument of The Great Transformation. In brief, it runs as follows: liberal political economy bears fundamental responsibility for the collapse of liberal civilisation; the response to the collapse is taking a variety of forms, including fascism, Soviet communism, and the New Deal; in sharply divergent ways, reactionary and progressive, these movements are constructing institutions of national re-integration; the urgent need now is for integration to continue globally, in socialist and regionalist forms. In the USA that would mean a radicalisation of the New Deal, centred on the removal of land, labour and money from determination by market forces. Polanyi himself sought to play a part. Of his two objectives in writing The Great Transformation, he later recalled (Polanyi n.d. a), one was 'to transplant into the English labour movement the spirit of the Austrian militant socialist workers' culture,' while the other was 'to give wings to Roosevelt's New Deal by an up-to-date critique of capitalism.'

Far from radicalisation, however, in the late 1930s the New Deal found itself impeded. Its reform programmes, despite claims by some chroniclers today (Pettifor 2019: 49, 53), did not 
bring 'the Great Depression to an end,' and prosperity had not returned already in 1933. Rather, growth flatlined, and unemployment remained at distressing levels until 1940. Many of the combative movements that had pressed for progressive change began to peter out, and the Republican Party gained electoral ground. The zenith of some radical initiatives, notably cooperative land-use planning, was not achieved until the early 1940s (Gilbert 2015), but most New Deal programmes had been attenuated or reined in by then.

Economic growth did eventually resurge, due to war mobilisation. As Polanyi (n.d. b) saw it, the nation under Roosevelt was able to 'switch its industrial potential to war production in as many months as Hitler took years to do.' This, he believed (Polanyi n.d. c), demonstrated 'democracy at its marvellous best.' Still, the question remained, could the war economy fundamentally transform economic relations? In 1943 he remarked to a friend (cited in Gräser 2019) that, in his understanding, the foundational triad of liberal capitalism - the fictitious commodities land, labour and money—had been abolished. Yet, either his understanding of decommodification was awry, or his spectacles were too tinted, for a capitalist war economy remains a capitalist economy. In sober mood, Polanyi noted that Roosevelt was shunting the USA and much of the world back towards 'the economics of the gold standard and free trade' (Polanyi 1940s), and at the end of the war he noted (Polanyi 1945) that the New Deal had barely 'affected the position of liberal capitalism.' Although it might yet 'prove the starting point of an independent-American - solution of the problem of an industrial society, and a real way out of the social impasse that destroyed the major part of Europe,' that day 'has not yet come.'

Polanyi was right to note the post-war recrudescence of 'liberal capitalism.' Yet this was no simple reversal. The New Deal administrations had transformed the US state, before and during the war. Military spending reignited economic growth, and the broader exigencies of war 
reinforced the hands-on governmental practices that had been trialled in the mid-1930s. The Tennessee Valley Authority, through its contribution to aluminium production and the Manhattan Project's atomic bomb, exemplified one way in which New Deal infrastructure was hitched to martial ends (Patel 2016). At a broader level, the New Deal—its ethos, sensibility, personnel and practices-led to the beefing up of America's state machinery, including new institutions of regulation and planning (Katznelson 2014). It was embedded in the rhetoric of US aims in war and in postwar reconstruction, in the Four Freedoms and the Atlantic Charter, in Washington's wartime planning institutions and its post-war construction of administrative and economic capacities, as well as institutions of soft power in Europe, Japan and beyond (Borgwardt 2005). In these ways, the New Deal contributed to the legitimation of American power politics. As Fred Block has argued (1977), the plans for international reform that sprang from the New Dealers, served to legitimise US imperial expansion in the aftermath of WWII, both among domestic liberals and abroad.

Consider for example Roosevelt's Vice President, Henry Wallace. He was a New Dealer whose 1948 presidential bid Polanyi strongly supported (Scammell 2009: 315-16), and also the bestknown booster for the US-led internationalisation of the New Deal. Destiny, he proclaimed (Wallace 1944), 'calls us to world leadership,' a role that required the USA to be more concerned 'with welfare politics and less with power politics, more attentive to equalizing the use of raw materials of nations than condoning the policies of grab and barter that freeze international markets, [and] more interested in opening channels of commerce than closing them by prohibitive tariffs.' In Wallace's vision of a global New Deal, colossal public works programmes would be unfurled, in the form of roads and airports and other infrastructure projects, which would bring tremendous profit to US business. 'American capital,' he exulted, 'can play a great constructive role — and a profitable role - in the development of the economies 
of other countries. It will provide us with enormous post-war foreign markets' (cited in Garfield 2013:79).

Other prominent New Dealers, notably Henry Morgenthau and Harry Dexter White, were key players in constructing the post-war architecture of world power, notably at Bretton Woods. The agenda there was to put American politicians, not private bankers, in charge of global finance, and to suppress speculative capital flows. The outcome facilitated America's hegemonic ascendancy by establishing the dollar as the world's currency. Polanyi was right to warn that Bretton Woods would strengthen and globalise liberal capitalism under US leadership. An imperialist restructuring of the world ensued, following the contours of the colonial era, with swathes of the Global South converted into extraction zones for Northern transnational corporations.

How, then, should Polanyi's ambivalences vis-à-vis the New Deal be understood? The basic shape of the answer is simple: they mirrored the contradictions of the New Deal itself. It incorporated major concessions to movements of workers and the poor, yet from the vantage point of those in power it was a project to restabilise capitalism, at first in the USA and then worldwide. The New Deal administrations legalised union organisation and collective bargaining, and were more aware of African-American concerns than previous administrations. Yet they also awarded corporate interests, and even Jim Crow, ${ }^{6}$ prime seats at the New Deal table, granted the state greater control over individuals' lives, and enforced draconian immigration controls that prepared the ground for McCarthyism. Polanyi revered Roosevelt, he of the Social Security Act, the Civilian Conservation Corps and the Federal Emergency Relief Administration, yet the same Roosevelt interned people of Japanese descent, refused to support anti-lynching legislation, authorised mass deportations of immigrants and launched

\footnotetext{
${ }^{6} \mathrm{Jim}$ Crow refers to racist laws enforcing segregation in the USA.
} 
America's oil grab in the Middle East. Secondly, Polanyi was confidently predicting a global 'great transformation' away from market capitalism, of which the New Deal represented the USA's variant. The foundering of that trend in the aftermath of the war necessarily brought with it interpretative difficulties. Thirdly, there were contradictions inherent in Polanyi's position of advocating socialist transformation while seeing the capitalist state as its principal vehicle.

Lacher's explanation is different. He believes that ambiguity entered Polanyi's strategic thinking, particularly in the final chapter of The Great Transformation, because whereas the book was aimed primarily at British and North American audiences, he was 'a (non-Marxian) revolutionary socialist on Britain and Europe, but less than a social democrat on America' (Lacher 2020). (An earlier version (Lacher 2017) uses a less oblique phrase: 'a reformist socialdemocrat on America.') On this, my reading is different. Polanyi, on whichever side of the Atlantic he sat, embraced a radical but non-revolutionary socialism. By 'radical' I refer to his advocacy of a transformation from capitalism to a cooperatively ordered society based on the decommodification of land, labour and money and with a major role for economic planning. By 'revolutionary socialist' I understand a political strategy predicated on two axioms: (i) capitalist states cannot be the vehicles of socialist transformation but must be confronted and ultimately dismantled, in a process that (ii) necessarily involves the active engagement of sections of the oppressed and exploited. With respect to (ii), Polanyi evidently wished for the New Deal to veer left, yet he paid scant attention to the social movements that could effect such a turn, notably the labour militancy of the mid to late 1930s. Indeed, he played down those struggles. The US union movement, he suggested (Polanyi 1937), is 'non-political'; it is 'almost state-made, a creation of the enlightened absolutism of Rooseveltian (New Deal) democracy.' As regards (i), Polanyi rightly receives acclaim for his thesis on the pivotal role played by states in engineering the market economy, but he paid little heed to the ways in which 
states in capitalist society are structurally geared to the interests and imperatives of capital accumulation. His analysis of the New Deal pays little attention to Roosevelt's strategies to defeat revolt (through repression and concessions), for he viewed the étatisme of the New Deal primarily as an element within a global structural shift. This approach was not, pace Lacher, distinctive to his views on the USA. It is a recurrent motif in his interpretation of twentiethcentury global politics. You find it for example in the duality in The Great Transformation between the 'conservative 1920s' and the 'revolutionary 1930s.' The terms designate not the scale or dynamic or success/failure of mass struggles but whether nineteenth-century institutions (liberal states and the gold standard) were being restored, as in the 1920s, or were being supplanted by dirigisme and economic nationalism-'revolutionary' moment as Polanyi saw it.

The New Deal, I have suggested, strengthened America's institutional capabilities, enabling it to fight the war more effectively and helping to legitimise its worldwide expansion. It laid the platform for the export of the US model of capitalism: suburbs-expanding, aviation-addicted, gasoline-slurping, car-luvvin, grotesquely wasteful and hideously militaristic. The golden age of what some Polanyians call 'embedded liberalism' was a carbon age, in which environmental despoliation proceeded at breakneck pace. Greenhouse gas emissions increased more rapidly than during any other period of history, bequeathing humanity today with the urgent need for... well, a GND?

\section{A Red-Green New Deal}

One can distinguish four broad strategic approaches to climate breakdown. The first can be called 'callous indifference,' and is represented by Donald Trump. 'Climate breakdown, who cares? It may be a threat, it may not. Either way, we'll carry on trashing the planet, its future means nothing to us. Maybe environmental apocalypse will come? If so, there's nothing we 
can do to stop it. We'll fiddle as it all burns.' The second we can call 'rationalist liberalism.' It possesses at least a basic literacy in climate science and is hegemonic in the European Union. It advocates green capitalism and green growth, with emissions to be curbed through international agreement, technological investment (notably in renewable energy and electric cars), and changing patterns of consumption. It identifies corporate ecological responsibility as a key driver of change (Dale 2008). For its part, government should steer and nudge industries and consumers using methods both fiscal (carbon taxes) and market based (tradable property rights in emissions). Investments are typically tied to a national goal: to become an export leader in the dawning green new world. The third is the GND. It overlaps with rational liberalism — indeed one of the earliest usages in English was by a neoliberal columnist, Thomas Friedman (2007) — and in the oncoming economic depression this convergence is likely to grow. A straw in the wind is the pro-GND editorial position of the Financial Times (editorial board 2020), and there is scope for further convergence, either in a 'neoliberal Green New Deal' (Adler and Wargan 2019) based around public-private partnerships, or in an economicnationalist version that prioritises eco-industrial supremacy. For the most part, however, GND supporters tend to alloy support for 'Hamiltonian' industrial policy (Meyer 2019) with socialdemocratic values, and to place strategic emphasis on state regulation, green jobs programmes, and the 'just transition.' ${ }^{7}$ Its leading proponents include Alexandria Ocasio-Cortez and Bernie Sanders; it looks to trade unions for support, supports climate jobs programmes and, on its left flank, it includes anti-capitalists who envision a far-reaching transformation towards an egalitarian, sustainable and radically democratic society. The fourth is degrowth. As a social movement, it 'started in Lyon in the wake of protests for car-free cities, meals in the streets, food cooperatives and anti-advertising' (Demaria et al. 2013). Degrowthers advocate

\footnotetext{
7 'Hamiltonian' refers to US politician Alexander Hamilton, who advocated state support for manufacturing industry.
} 
fundamental social and economic change, including a sharp reduction in consumption in the rich world and a turn from industrial agriculture to agro-ecology and permaculture. Most of them emphasise change 'from below' and identify as feminists and anti-capitalists (Eversberg and Schmelzer 2018), although some adopt a more constrained, individual-ethical, agenda of frugal living (Schoppek 2020). I see the degrowth movement as narodnik, in that it is centred around leftist intellectuals, with 'commoning,' 'small is beautiful' and 'back to the land' dispositions (see Dale 2019). Among degrowthers, references to Polanyi, in particular his 'embeddedness' theorem, is not uncommon (Muraca 2013).

These four positions define the tragedy of climate politics as it is playing out today. The first is a death cult. Its proponents, in the USA, China and elsewhere, have promptly used the coronavirus crisis as a pretext to suspend or repeal environmental regulations (Standaert 2020). If they advocate any climate change mitigation at all, it is tokenistic and trivial. (Their typical proposal is reforestation, which, although urgently needed, when proposed as the sole climate mitigation measure is but another brand of denial, designed to occlude the ongoing cause of the crisis, viz., the siphoning of carbon from lithosphere into atmosphere. Trees, ultimately, rot or burn, returning their bodies unto the air.) The second fetishizes technology, peddles consoling illusions in 'net zero' (Allwood 2020), ignores the problem of rebound effects, and wishes for renewable energy to power the engines of capital accumulation. Although an increasingly hegemonic project since the 1990 s, it has been unable to navigate emissions reductions at anything remotely approaching the speed required. The gap between its laudable environmental goals and its abject failure to meet them is filled by magical thinking (with respect to the promise of technology) and torrents of greenwash. The third, the GND, is in danger of becoming little but a snappy brand name for the second, while the fourth possesses a clear-eyed view of the dimensions of the crisis, but its programmes struggle to find mass resonance. 
Early warnings of the hijacking of the GND arrived in 2008-9 when, in the midst of the Great Recession, South Korea and China launched 'green' stimulus packages. These, when you look at the small print, contained thimbles of ecological benefit but gallons of environmental despoliation, alongside large dollops of governmental and corporate spin (Dale 2015). Both countries' carbon emissions continued to rise. A more recent example is South Korea's GND, announced by the incoming Moon Jae-in government in spring 2020. Over ten years, the plan would cut emissions by ‘37\% below projected business-as-usual levels’ (Farand 2020). This may sound significant but it would not even meet South Korea's share of reductions necessary to fulfil the pledge in the Paris Agreement to limit global heating to below $2^{\circ} \mathrm{C}$. Moon's GND makes no mention of the need to phase out internal combustion engine vehicles, nor does it contain a plan to reach 'net zero' emissions (let alone zero emissions) by 2050 (Vetter 2020). Within a fortnight of its announcement, the Moon administration authorised a \$2 billion bailout - with no social or environmental strings attached—of Doosan Heavy Industries \& Construction, one of the world's largest coal exporters (Shorrock 2020; Farand 2020).

In current discussion of the GND, what inspiration do its supporters find in Roosevelt's New Deal and war mobilisation? Front and centre is the government-led leveraging of economic transformation. As Ocasio-Cortez sees it (cited in Meyer 2019), government could deploy the tools of the present ('public-private partnerships') but could turn to those of the New Deal: 'Tennessee Valley Authority-style public programs.' Relatedly, they look to the speed and breadth of war mobilisation. The war economy was not left to market forces. Planning played a major part. Government, with large-scale popular backing, directed big business to produce equipment for the war front, just as it could today on the 'climate front.' Government also suppressed entire industries (such as house construction), much as it could today (such as aviation, automobiles and fossil fuels). 
Although often forgotten, tremendously inspiring activity also occurred on the home front (or the 'social-reproduction front'). That front, as the American socialist Mike Davis describes (2007), constituted 'the most important and broadly participatory green experiment in U.S. history.' In the 1940s, he recalls,
'my parents, their neighbors, and millions of others left cars at home to ride bikes to work, tore up their front yards to plant cabbage, recycled toothpaste tubes and cooking grease, volunteered at daycare centers, shared their houses and dinners with strangers, and conscientiously attempted to reduce unnecessary consumption and waste.... Victory gardening transcended the need to supplement the wartime food supply and grew into a spontaneous vision of urban greenness and self-reliance. ... The war also temporarily dethroned the automobile as the icon of the American standard of living [and] the bicycle made a huge comeback.'

One could envisage a GND replicating this 'People's War'-for example by converting suburbia's lawns and golf courses to agro-ecological cultivation.

A further lesson for the GND today, and one of which Polanyi was insufficiently aware, is that these transformative processes were driven by mass movements. The Roosevelt administration did not enter office with the intention of swapping orthodox liberal austerity for socialdemocratic programmes. A decisive factor was the movement upsurge of unemployed and working people. There were hunger marches, rent strikes and labour militancy, including use of mass pickets and frequently with communist activists in organising roles (Kerl 2020). As Naomi Klein relates (2019), there was 'the Teamster Rebellion and the Minneapolis general strike in 1934, the eighty-three-day shutdown of West Coast ports by longshore workers that same year, and the Flint autoworkers sit-down strikes in 1936 and 1937.' It was this pressure from the left, she adds, that delivered the most progressive elements of the New Deal. Equally, 
the same period reminds us that where movement leaderships, in the desire to influence policy, tie themselves too closely to state institutions, their organisational and mobilising capacities tend to wither (Hart-Landsberg 2020b).

These, then, are the sources of inspiration in Rooseveltian America for GND campaigners today, but the analogy has limits. In the war, capital could get fully behind Roosevelt's programme. Big corporations were eager to lead the war-time conversion process (HartLandsberg 2020a). They were primed to benefit from the massive boost in demand, and from the destruction and devaluation of foreign rivals. This latter was a gamble predicated on martial success, but with the USA entering in 1943 it was a good bet. Victory promised further benefits to US capital, through Washington's domination of much of the world, with previously protected markets cracked open and control gained over global oil supplies. A GND, by contrast, will have to offer drastic demand reduction in many more sectors, and it does not promise global domination (even if in current iterations the nation's prospective leadership in green tech is highlighted). On the contrary, success, especially in addressing climate breakdown and other environmental challenges, will require unequivocal internationalism. When compared with war mobilisation, therefore, incomparably greater resistance from capital can be expected - at least if the GND is to have real traction rather than be a greenwashing of 'business as usual.' That is why, if a GND is to take seriously the needs of 'life making' on a habitable planet, it would need to turn red-green — a 'radical GND,' to use the term of Kate Aronoff and her colleagues (2019), or a 'people's GND,' to use Max Ajl's (2020). Unlike Roosevelt's New Deal it would have to be radical in terms of popular democratic participation and emissions reductions. It would have to reduce overall material consumption and energy demand (Kolinjivadi and Kothari 2020). It would have to be global in reach, avoiding extractivist imperialism. It would have to confront vested interests and advocate anti-capitalist values. 


\section{REFERENCES}

Adler, D. and P, Wargan. 2019. 'Stop polluting our Green New Deal.' Jacobin. https://jacobinmag.com/2019/06/green-new-deal-europe-capitalism (accessed 2 January 2020).

Ajl, M. 2020. 'Clean tech versus a People's Green New Deal,' www.earthisland.org/journal/index.php/magazine/entry/clean-tech-versus-a-peoplesgreen-new-deal/ (accessed 20 May 2020)

Allwood, J. 2020. 'Absolute zero.' The Ecologist, https://theecologist.org/2020/mar/24/absolute-zero (accessed 20 May 2020)

Aronoff, K. et al. 2019. A Planet to Win: Why We Need a Green New Deal. London: Verso.

Berger, K. 2020. 'The man who saw the pandemic.' http://nautil.us/issue/83/intelligence/theman-who-saw-the-pandemic-coming (accessed 20 April 2020)

Bhattacharya, T. and Dale, G. 2020. 'Covid Capitalism: General tendencies, possible "leaps."” Spectre Journal, https://spectrejournal.com/covid-capitalism/ (accessed 2 May 2020).

Block, F. 1977. The Origins of International Economic Disorder: A Study of United States International Monetary Policy from World War II to the Present. Berkeley: University of California Press.

https://doi.org/10.1086/ahr/82.5.1352-a

Boffey, D. 2020. 'Big pharma rejected EU plan to fast-track vaccines in 2017.' The Guardian, 25 May, www.theguardian.com/world/2020/may/25/exclusive-big-pharmarejected-eu-plan-to-fast-track-vaccines-in-2017 (accessed 25 May 2020).

Borgwardt, E. 2005. A New Deal for the World: America's Vision for Human Rights. Cambridge, MA: Harvard University Press.

Carton, W. 2014. 'Environmental protection as market pathology?: Carbon trading and the dialectics of the "double movement." Environment and Planning D: Society and Space32: 1002-1018.

https://doi.org/10.1068/d13038p

Chase-Dunn, C. and K. Lawrence. 2011. 'The next three futures, part one: Looming crises of global inequality, ecological degradation, and a failed system of global governance.' Global Society25(2): 137-153.

https://doi.org/10.1080/13600826.2011.553525

Dale, G. 2008. "'Green Shift”: An analysis of corporate responses to climate change.' International Journal of Management Concepts and Philosophy3(2): 134-155.

Dale, G. 2009. 'Karl Polanyi in Budapest: On his political and intellectual formation.' Archives Européennes de Sociologie / European Journal of Sociology50(1): 97-130.

Dale, G. 2012. 'Adam Smith's green thumb and Malthus' three horsemen: Cautionary tales from classical political economy.' Journal of Economic Issues46(4): 859-879.

https://doi.org/10.2753/jei0021-3624460402

Dale, G. 2015. 'Origins and delusions of green growth.' International Socialist Review97, https://isreview.org/issue/97/origins-and-delusions-green-growth (accessed 20 May 2020).

Dale, G. 2016a. 'In search of Karl Polanyi's international relations theory.' Review of International Studies42(03): 401-424.

Dale, G. 2016b. Karl Polanyi: A Life on the Left, New York: Columbia University Press.

Dale, G. 2016c. Reconstructing Karl Polanyi: Excavation and Critique, London: Pluto Press. 
Dale, G. 2017. 'After 1917: Civil war and "modernising counter-revolution." rs21, www.rs21.org.uk/2017/10/26/revolutonary-reflections-after-1917-civil-war-andmodernising-counter-revolution/ (accessed 20 May 2020).

Dale, G. 2019. 'Degrowth and the Green New Deal.' The Ecologist, https://theecologist.org/2019/oct/28/degrowth-and-green-new-deal (accessed 20 May 2020).

Davis, M. 2007. 'Home front ecology.' www.resilience.org/stories/2007-07-10/what-ourgrandparents-can-teach-us-about-saving-world/ (accessed 9 April 2018).

Demaria, F. et al. 2013. 'What is degrowth? From an activist slogan to a social movement.' Environmental Values22(2): 191-215.

https://doi.org/10.3197/096327113x13581561725194

Doward, J. 2020. 'Government under fire for failing to act on pandemic recommendations.' The Guardian, 19 April, www.theguardian.com/world/2020/apr/19/government-underfire-failing-pandemic-recommendations (accessed 20 May 2020).

Dunne, D. 2020. 'Could climate change and biodiversity loss raise the risk of pandemics?' Carbon Brief, www.carbonbrief.org/q-and-a-could-climate-change-and-biodiversityloss-raise-the-risk-of-pandemics (accessed 20 May 2020).

Editorial board. 2020. 'The virus fight opens up a climate opportunity.' Financial Times, 15 May, www.ft.com/content/eb683e52-95d0-11ea-abcd-371e24b679ed (accessed 20 May 2020).

Eversberg, D. and M. Schmelzer. 2016. 'The degrowth spectrum: Convergence and divergence within a diverse and conflictual alliance.' Environmental Values27:245-267. https://doi.org/10.3197/096327118x15217309300822

Farand, C. 2020. 'South Korea to implement Green New Deal after ruling party election win.' www.climatechangenews.com/2020/04/16/south-korea-implement-green-new-dealruling-party-election-win/ (accessed 20 May 2020)

https://doi.org/10.1108/oxan-es245316

Friedman, T. 2007. 'The power of green.' New York Times, 15 April. www.nytimes.com/2007/04/15/opinion/15iht-web-0415edgreen-full.5291830.html (accessed 7 November 2018).

Garfield, S. 2013. In Search of the Amazon: Brazil, the United States, and the Nature of a Region. Durham: Duke University Press.

Gilbert, J. 2015. Planning Democracy: Agrarian Intellectuals and the Intended New Deal. Newhaven: Yale University Press.

https://doi.org/10.12987/yale/9780300207316.001.0001

Gräser, M. 2019. 'Historicizing Karl Polanyi.' Österreichische Zeitschrift für Soziologie44: $129-141$.

https://doi.org/10.1007/s11614-019-00332-9

Hart-Landsberg, M. 2020a. 'The Green New Deal and the state: Lessons from World War II.' Monthly Review, https://mronline.org/2020/04/08/the-green-new-deal-and-the-statelessons-from-world-war-ii-part-i/ (accessed 20 May 2020).

https://doi.org/10.1515/9781400854257.fm

Hart-Landsberg, M. 2020b. 'What the New Deal can teach us about winning a Green New Deal.' Class, Race and Corporate Power8(1).

Holleman, H. 2018. Dust Bowls of Empire: Imperialism, Environmental Politics, and the Injustice of 'Green' Capitalism. Newhaven: Yale University Press.

https://doi.org/10.12987/yale/9780300230208.003.0001

Holmes, C. 2018. Polanyi in Times of Populism: Vision and Contradiction in the History of Economic Ideas. London: Routledge.

https://doi.org/10.4324/9781315396989 
Katznelson, I. 2014. Fear Itself: The New Deal and the Origins of Our Time. New York: Liveright.

Kerl, E. 2020. 'Chicago's unemployed rebellion.' https://rampantmag.com/2020/05/18/chicagos-unemployed-rebellion/ (accessed 20 May 2020).

Klein, N. 2019. On Fire: The Burning Case for a Green New Deal. Harmondsworth: Penguin

Kolinjivadi, V. \& A. Kothari. 2020. 'No harm here is still Harm there: The Green New Deal and the Global South.' www.jamhoor.org/read/2020/5/20/no-harm-here-is-still-harmthere-looking-at-the-green-new-deal-from-the-global-south (accessed 20 May 2020).

https://doi.org/10.1186/s12954-018-0242-x

Lacher, H. 1999. 'Embedded Liberalism, disembedded markets: Reconceptualising the pax Americana.' New Political Economy4(3): 343-360.

https://doi.org/10.1080/13563469908406408

Lacher, H. 2006. Beyond Globalization: Capitalism, territoriality and the international relations of modernity. London: Routledge.

https://doi.org/10.4324/9780203299654

Lacher, H. 2017. 'Karl Polanyi, The Great Transformation, and the American exception.' Manuscript shared with the author.

Lacher, H. 2020. 'Multilinear trajectories: Polanyi, The Great Transformation, and the American exception.'

www.researchgate.net/publication/335877603_\%27\%27Multilinear_Trajectories_Polan yi_The_Great_Transformation_and the American_Exception\%27_in_Radhika_Desai and_Kari_Polanyi_Levitt_Eds_Karl_Polanyi_and_21st_Century_Capitalism_2020_pp_ 164-88 (accessed 20 May 2020).

https://doi.org/10.7765/9781526127891.00016

Le Quéré, C. et al. 2020. 'Temporary reduction in daily global CO2 emissions during the COVID-19 forced confinement.' Nature Climate Change, 19 May. www.nature.com/articles/s41558-020-0797-x (accessed 21 May 2020).

Meyer, R. 2019. 'A centuries-old idea could revolutionize climate policy.' The Atlantic, www.theatlantic.com/science/archive/2019/02/green-new-deal-economicprinciples/582943/ (accessed 20 May 2020).

Milman, O. 2020. 'Pandemic side-effects offer glimpse of alternative future on Earth Day 2020.' The Guardian, 22 April, www.theguardian.com/environment/2020/apr/22/environment-pandemic-side-effectsearth-day-coronavirus (accessed 20 May 2020).

Muraca, B. 2013. 'Décroissance: A project for a radical transformation of society.' Environmental Values22(2):147-169.

Patel, K. K. 2016. The New Deal: A Global History. Princeton: Princeton University Press. Pettifor, A. 2019. The Case for the Green New Deal. London: Verso.

Polanyi, K. 1922. 'Titáni publicisztika' [Titanic journalism]. English translation by Adam Fabry, reproduced in G. Dale (ed.), Karl Polanyi: The Hungarian Writings. Manchester: Manchester University Press.

Polanyi, K. 1933. 'Roosevelt zerschlägt die Konferenz.' In Michele Cangiani and Claus Thomasberger (eds), Chronik der großen Transformation, Band 1, Marburg: Metropolis.

Polanyi, K. 1937. Letter to [Toni Stolper?], June 24, Container 47, folder 8, Karl Polanyi Archive, Concordia University.

Polanyi, K. 1940. Letter to Ilona Duczynska, 21 November. Container 59, folder 7, Karl Polanyi Archive, Concordia University. 
Polanyi, K. 1940s. 'Book outline and introduction "Tame Empires."' This text, in Container 20 folder 2 of the Karl Polanyi Archive (Concordia University), is listed in the archive catalogue as $1938-39$ but it is indubitably from the early 1940 s.

Polanyi, K. 1945. 'Universal Capitalism or Regional Planning?' London Quarterly of World Affairs10(3).

Polanyi, K. 2001. The Great Transformation: The Political and Economic Origins of Our Time, Boston: Beacon Press.

Polanyi, K. early 1920s a. 'A félelem ellen' [Against fear], Bécsi Magyar Ujság article, Container 1, folder 51, Karl Polanyi Archive, Concordia University.

Polanyi, K. early 1920s b. 'Van-e Mosszulban petroleum?' [Is there oil in Mosul?], Bécsi Magyar Ujság article, Container 1, folder 51, Karl Polanyi Archive, Concordia University.

Polanyi, K. n.d. a. 'Bibliography: 1920-1960.' Container 29, folder 8, Karl Polanyi Archive, Concordia University.

Polanyi, K. n.d. b. 'Lecture, "Friends of democratic Hungary: America 1943,"” Container 18, folder 25, Karl Polanyi Archive, Concordia University.

Polanyi, K. n.d. c. Interview: 'In post-Pearl Harbour America I learnt to know democracy at its best.' Container 30, folder 1, Karl Polanyi Archive, Concordia University.

Polanyi, K. 1936. 'Outline, political and economic experiments in our time. U.S.A and New Deal.' Container 1, folder 51, Karl Polanyi Archive, Concordia University. The date of publication is not confirmed. My best guess is 1936 .

Scammell, M. 2009. Koestler: The Literary and Political Odyssey of a Twentieth-Century Skeptic. New York: Random House.

Schoppek, D. E. 2020. 'How far is degrowth a really revolutionary counter movement to neoliberalism?' Environmental Values29(2): 131-151.

https://doi.org/10.3197/096327119x15579936382491

Scott, J. 2017. Against The Grain: A Deep History of the Earliest States, Newhaven: Yale University Press.

Shorrock, T. 2020. 'Electoral triumph spurs Green New Deal in South Korea.' The Nation, www.thenation.com/article/world/south-korea-elections-climate/ (accessed 20 May 2020).

Standaert, M. 2020. 'China relaxes environmental rules to curb virus's economic hit.' https://news.bloomberglaw.com/environment-and-energy/china-relaxes-environmentalrules-to-curb-viruss-economic-hit (accessed 20 May 2020).

Stuart, D. et al. 2019. 'Climate change and the Polanyian counter-movement: Carbon markets or degrowth?' New Political Economy24(1):89-102.

https://doi.org/10.1080/13563467.2017.1417364

Vetter, D. 2020. 'South Korea embraces EU-style Green Deal for COVID-19 recovery.' Forbes, www.forbes.com/sites/davidrvetter/2020/04/16/south-korea-embraces-eu-stylegreen-deal-for-covid-19-recovery/\#1a83a2f65611 (accessed 20 May 2020).

Wallace, H. 1944. Democracy Reborn, Cornwall Press, https://archive.org/stream/in.ernet.dli.2015.77313/2015.77313.DemocracyReborn djvu.txt (accessed 20 May 2020).

Wallace, R. 2016. Big Farms Make Big Flu: Dispatches on Influenza, Agribusiness, and the Nature of Science, New York University Press. 